\title{
Chlapec se srdcem na pravém místě a orgány na rozdávání
}

\section{MUDr. Martin Gregora}

\section{Dětské oddělení Nemocnice Strakonice, a. s.}

Klíčová slova: situs viscerum inversus, dextrokardie, akcesorní slezina, Kartagenerův syndrom, ciliární dyskinese.

Key words: situs viscerum inversus, dextrocardia, accessory spleen, Kartagener syndrome, ciliary dyskinesia.

12letý chlapec byl odeslán praktickým lékařem k rutinnímu ambulantnímu sonografickému vyšetření pro intermitentní bolesti břicha trvajícíasi 14 dnů. Vyjma mírné palpační citlivosti v pravém epigastriu se chlapcův somatický nález jevil normální. Dosud vážněji nestonal, závodně sportuje.

Při UZ vyšetření bylo nápadně patrné, že kličky tlustého střeva se zobrazily v pravém mesogastriu, jaterní lalok byl odtlačen ke střední čáre a na jeho místě byly detekovány čtyři oválné rezistence homogenní struktury, jejichž echogenita odpovídala parenchymatózním orgánům.

Chlapec byl odeslán na CT vyšetření břicha k upřesnění diagnózy. Výsledek byl překvapivý: situs viscerum inversus. Slezina uložená vpravo pod

Obr. 1. Situs inversus: Tračník vyplňuje pravou polovinu bricha a pánve. Játra uložená vlevo (štíhlá šipka), levý lalok presahuje střední čáru doprava do přední axilární čáry; silnějši šipka ukazuje na slezinu

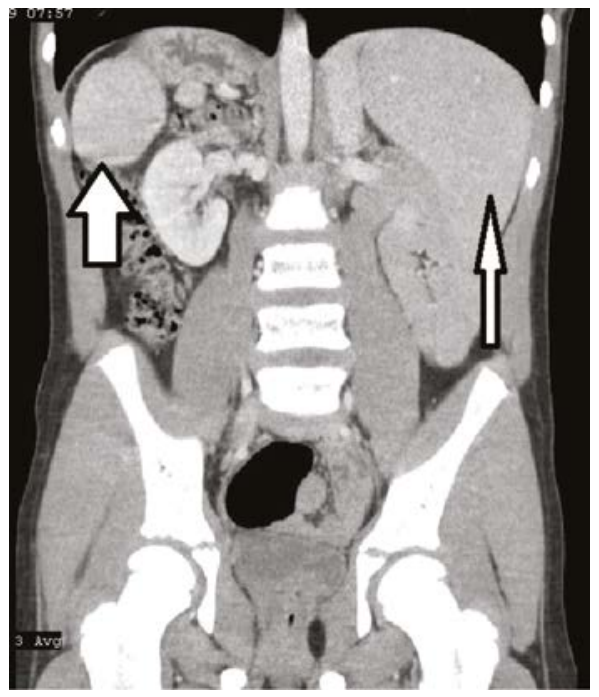

Obr. 2. Akcesorní sleziny: vlevo uložený žaludek a slezina s dalšími 3 akcesorními slezinami (šipky) rüzné velikosti

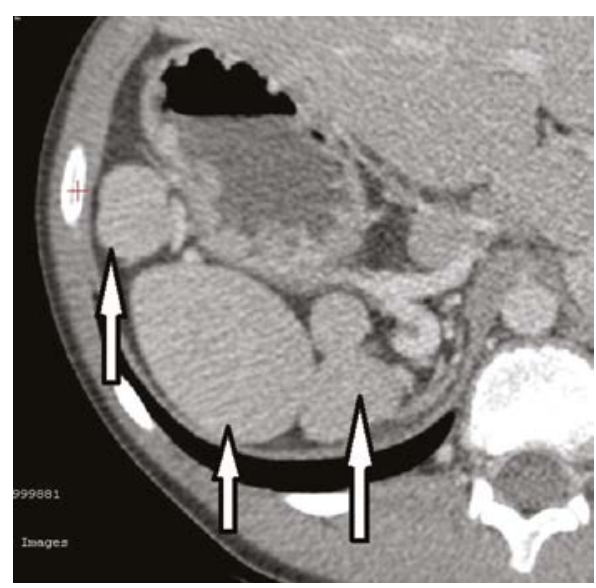

Obr. 3. Dextrokardie-RTG plic (P - pravá strana, L- levá strana)

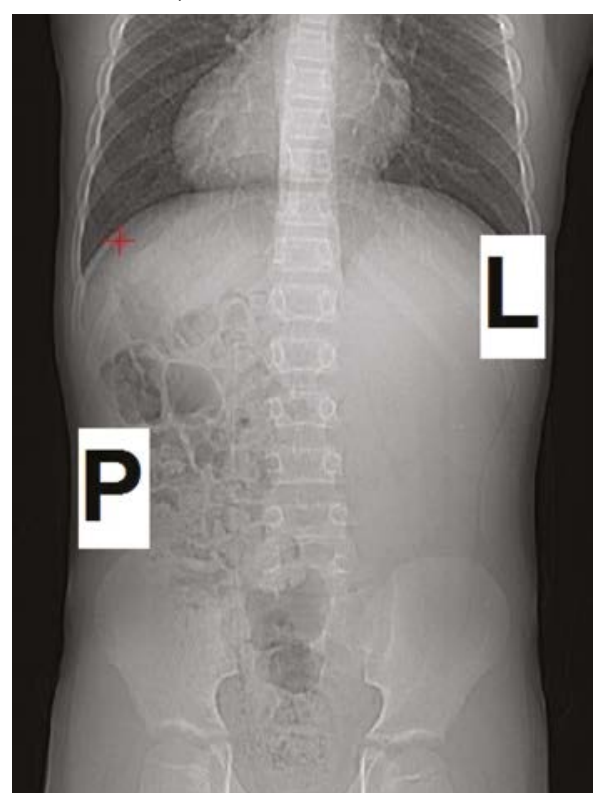

bránicí, dále tř̌i menší akcesorní sleziny, játra vlevo pod bránicí, mírně zvětšená, zvláště levý lalok, který přesahuje střední čáru doprava do přední axilární čáry. Uložení hưře přehledného pankreatu je sporné, spíše kolem střední čáry a doleva. Žaludek uložený vpravo. Tračníkje uložený v pravé polovině brìcha a pánve, zatímco tenké kličky vlevo. Ledviny normálně uložené, nález přiměřený. Aorta paravertebrálně vpravo, dolní dutá žíla vlevo. Vyšetření současně prokázalo také dextrokardii.

Před 2 lety byl chlapci proveden RTG snímek plic pro podezření na bronchopneumonii, nález byl hodnocen jako normální. Dextrokardie zde nebyla popsána. Zjevně byl snímek stranově špatně označen.

Situs viscerum inversus (SVI) může být neočekávaným překvapením pro chirurga, řešícího náhlou př́hodu břišní, ale může se pojit také s některými vzácnými onemocněními,

Obr. 4. RTG snímek plic provedený pred 2 lety; šipka ukazuje na chybně umistěnou značku "L"

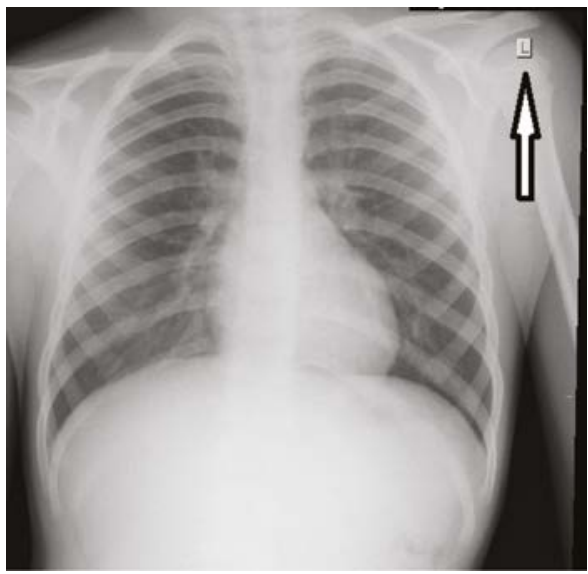

KORESPONDENČNÍ ADRESA AUTORA: MUDr. Martin Gregora, deo-prim@nemst.cz Dětské oddělení Nemocnice Strakonice, a. s. Radomyšlská 336, 38601 Strakonice
Cit. zkr: Pediatr. praxi. 2019 20(4): 259-260

Článek príijat redakcí: 3. 6. 2019

Článek prijat k publikaci: 14. 6. 2019 


\section{ORBIS PICTUS MEDICUS}

jako je ciliární dyskineze (recesivně dědičně vázaná heterogenní porucha motility řasinek spojená s chronickým otosinopulmonálním onemocněním, v přibližně v 50 \% prípadů bývají současně defekty orgánové laterality - Kartagenerův syndrom - situs inversus, chronická sinusitis, bronchiektázie, někdy i oligospermie či azoospermie). Byla popsána také

\section{LITERATURA}

1. Knowles MS, Zariwala M, Leigh M. Primary ciliary dyskinesia. Clin Chest Med 2016; 37 (3): 449-461.

2. Mishra M, Kumar N, Jaiswal A, Verma AK, Kant S. Kartage- asociace SVI s hepatocelulárním karcinomem či karcinomem duodena.

Akcesorní slezina se vyskytuje až u 15 \% populace. Jak častá je vícečetná akcesorní slezina, literatura neuvádí.

Anatomická anomálie je pro našeho pacienta potenciálním rizikem, ale v tomto prípadě i príznivým nálezem. Vyloučila podež̌ení na tumorózní

ner's syndrome: A case series, Lung India 2012; Oct;29(4): 366-369.

3. Mittal V, Shah A. Situs inversus totalis: the associati- expanzi v dutině břišní. Chlapec netrpí na záněty dýchacích cest, spojení s plicním onemocněním (ciliární dyskineze) je u něho nepravděpodobné. $\checkmark$ brzké době podstoupí ještě kompletní kardiologické vyšetření včetně ECHO.

Poděkování: prof. Doleželovi a doc. Votavovi za cenné rady a pripomínky.

on of Kartagener's syndrome with diffuse bronchiolitis and azoospermia. Arch Bronconeumol. 2012; May;48(5): 179-182. 